\title{
INFLUENCE OF DIFFERENT DRYING TECHNIQUES ON PHYSIOCHEMICAL AND NUTRITIONAL QUALITY OF MAIZE (Zea mays) GRAIN
}

\author{
AMARASEKARA SWGN, FATHIMA JEMZIYA MB*, AHAMED RIFATH MR \\ Department of Biosystems Technology, Faculty of Technology, South Eastern University of Sri Lanka, Oluvil, Sri Lanka. \\ Email: jemziya@seu.ac.lk
}

Received: 03 July 2021, Revised and Accepted: 22 August 2021

\section{ABSTRACT}

Objectives: This study attempt to investigate the appropriate drying methods for post-harvest storage of maize grains with preserving important quality and physiochemical characteristics.

Methods: The maize samples were dried using different drying methods such as field drying, greenhouse drying, solar drying, direct fire drying, hot air drying, and forced air drying. Further, the dried maize grains were analyzed for physical parameters of bulk density, particle density, porosity, specific gravity, shrinkage, and color. The proximate composition of dried maize grains was analyzed for crude protein, fiber, fat content, moisture, and ash content.

Results: There were significant differences $(\mathrm{p}<0.05)$ observed for bulk density, particle density, porosity, specific gravity, shrinkage, and color between different drying techniques. When considering proximate analysis, protein, moisture, and ash content were shown significant differences ( $\mathrm{p}<0.05$ ) between different drying methods. Whereas, fat and fiber content of samples were not shown a significant difference (p>0.05) for different drying methods.

Conclusion: Different drying methods affect the quality and physiochemical properties of maize grains. Among different drying techniques, the forced air oven drying method preserved physiochemical and nutritional properties considerably compared to other drying techniques.

Keywords: Drying techniques, Maize grains, Physiochemical characteristics, Proximate composition, Quality.

(C) 2021 The Authors. Published by Innovare Academic Sciences Pvt Ltd. This is an open access article under the CC BY license (http://creativecommons. org/licenses/by/4.0/) DOI: http://dx.doi.org/10.22159/ijags.2021v9i5.42624. Journal homepage: https://innovareacademics.in/journals/index.php/ijags

\section{INTRODUCTION}

Grain drying is essential for maintaining grain quality and safe storage [1]. A high amount of moisture content during storage enables the growth of fungi that produce highly toxic compounds. Therefore, it will lead to decreased product quality and shelf life. Maize grains are dried to limit microbial development, reduce enzymatic reactions, and extend storage life. [2]. In addition, it lowers grain weight, making transportation, and handling easier [3].

Conduction drying, convection drying, radiation drying, dielectric drying, chemical or sorption drying, vacuum drying, and freeze-drying are some of the maize drying processes used today. The qualitative characteristics of dried grains appear to be affected by physicochemical changes that occur during drying [4]. Color, esthetic appeal, texture, form, nutrient retention, water activity, chemical stability, density and porosity, and sorption properties of materials are all affected by the drying technique and process conditions [5]. The engineering properties of dried products and qualities that are connected to product quality are the two primary categories of features that are usually studied in dried grain products. Dried grain engineering characteristics are critical in the design of drying processes and processing equipment, as well as in the effective operation and management of processing facilities [6]. Effective moisture diffusivity, effective thermal conductivity, specific heat, equilibrium moisture content, and viscosity are all engineering characteristics of dry grain. The objective of this study is to find out the appropriate drying method for maize grains with preserving important quality and physiochemical characteristics.

\section{METHODS}

\section{Study area}

The experiments were conducted at the Food Science and Technology Laboratory, Faculty of Technology, South Eastern University of Sri Lanka.

\section{Sample preparation}

A selected maize variety (Jet 999) was hand-harvested randomly at maturity stage. After the harvest, husks were removed and granulated manually.

\section{Drying procedure}

NAD was carried out by exposing the maize grains in the hot humid sun at $30 \pm 5^{\circ} \mathrm{C}$ and $75 \pm 5 \%$ R.H. The maize sample was dried in the greenhouse at $45^{\circ} \mathrm{C}$ average temperature and $55 \%$ relative humidity. The average daily temperature during SD (ONT SD-001, Sri Lanka) was $36.7^{\circ} \mathrm{C}$ and the relative humidity was $55 \%$. HAD was carried out in a hot air oven (WOF-155, China) at $105^{\circ} \mathrm{C}$ temperature with an airflow rate of $1 \mathrm{~m} / \mathrm{s}$, and air humidity was regulated at $\approx 20 \%$. The direct fire drying was undertaken at around $200^{\circ} \mathrm{C}$ for $8 \mathrm{~h}$. FAD method was performed in a laboratory scale forced air drier (BOV-V230F, China) at $105^{\circ} \mathrm{C}$ (Table 1 ). The experiments were carried out until reach the moisture content of $15 \%$. The moisture was measured using a grain moisture meter (LDS-1H, China). The moisture content was recorded at 2 -h intervals during the drying process. The dried grain samples were packed in an airtight and moisture-proof container after it reaches 15\% moisture content for further analysis.

\section{Physical characteristics of maize grains \\ Bulk density}

The bulk density $\left(\oint_{\mathrm{b}}\right)$ was determined by filling dried maize grain to $100 \mathrm{ml}$ measuring cylinder, the bottom of which was tapped the top level with the palm without leaving any air space, then weighed the contents [7].

$$
\left(\mathrm{b}_{\mathrm{t}}\right)=\frac{\mathrm{W}_{\mathrm{S}}}{\mathrm{V}_{\mathrm{s}}}
$$

Where;

$6_{b}-$ the bulk density in $\mathrm{kg} \mathrm{m}^{-3}$; 
Table 1: Different drying techniques and drying temperatures ranges

\begin{tabular}{llll}
\hline Abbreviation & $\begin{array}{l}\text { Definition of the } \\
\text { process }\end{array}$ & $\begin{array}{l}\text { Drying } \\
\text { temperature }\end{array}$ & $\begin{array}{l}\text { Drying } \\
\text { time }\end{array}$ \\
\hline NAD & $\begin{array}{l}\text { On farm natural air } \\
\text { drying }\end{array}$ & $25-35^{\circ} \mathrm{C}$ & $40 \mathrm{~h}$ \\
GHD & Greenhouse drying & $40-50^{\circ} \mathrm{C}$ & $24 \mathrm{~h}$ \\
SD & Solar drying & $32-35^{\circ} \mathrm{C}$ & $28 \mathrm{~h}$ \\
HAD & Hot air drying & $105^{\circ} \mathrm{C}$ & $5 \mathrm{~h}$ \\
DFD & Direct fire drying & $200^{\circ} \mathrm{C}$ & $4 \mathrm{~h}$ \\
FAD & Forced air drying & $105^{\circ} \mathrm{C}$ & $5 \mathrm{~h}$ \\
\hline
\end{tabular}

$\mathrm{W}_{\mathrm{S}}$ is the weight of the sample in $\mathrm{kg}$;

$\mathrm{V}_{\mathrm{S}}$ is the volume occupied by the sample in $\mathrm{m}^{3}$

\section{Particle density}

The particle density $\left(\mathrm{q}_{\mathrm{t}}\right)$ was determined using the toluene displacement method. In this procedure, a $25 \mathrm{ml}$ measuring cylinder was filled with toluene, and the same mass of sample taken for bulk density was placed in the vessel holding toluene. The displacement of toluene level in the vessel when introducing maize grains was measured. The ratio of the mass of maize grains to the volume of displaced gave the particle density [8].

$$
\text { Particle density }\left(\oint_{t}\right)=\frac{W_{S}}{V 1-V 2}
$$

Where,

$\mathrm{W}_{\mathrm{s}}$ : Weight of the sample $(\mathrm{kg})$

V1: Total volume of solution

V2: Transferred volume of solution (ml)

\section{Porosity}

The porosity of maize grain was calculated using bulk and particle densities [7].

Porosity $(\varepsilon) \%=\frac{1-\frac{p_{b}}{p_{t}}}{p_{t}} \times 100$

Where,

$\mathrm{p}_{\mathrm{b}}$ : Bulk density $\left(\mathrm{kgm}^{-3}\right)$

$\mathrm{f}_{\mathrm{t}}$ : Particle density $\left(\mathrm{kgm}^{-3}\right)$

Specific gravity

Specific gravity was determined as the ratio between the maize grains density and water density.

$$
\text { Specific gravity }=\frac{\text { Weight in air } \times \text { Sp. gravity of water }}{\text { Weight of displaced water }}
$$

\section{Shrinkage}

The shrinkage percentage was determined by the following equation,

$$
\text { Shrinkage }(\%)=\left(M_{0}-M_{f}\right) \times * 1.176 \%
$$

$\mathrm{M}_{0}$ : Initial moisture content,

$\mathrm{M}_{\mathrm{f}}$ : Final moisture content in percent,

*Water shrinkage factor for $15 \%$ moisture content in maize grain.

\section{Proximate composition of maize}

Proximate analysis was determined by near-infrared spectroscopy (DS2500F, USA). The instrument was calibrated before analysis according to wavelength and intensity correction.

\section{Color measurement}

The color of maize grains was measured using a colorimeter (CHN Spec, CS 10, China). The colorimeter was calibrated with a white surface.
Measurements were recorded as L (lightness), $+\mathrm{a}$ (redness), and $+\mathrm{b}$ (yellowness) CIE color coordinates.

\section{Statistical analysis}

The data were analyzed using SPSS statistical package (SPSS 20.0, IBM, New York, NY, USA). The analysis of variance was used to find the significant differences, and means were compared using Tukey's post hoc test at $5 \%$ significant level.

\section{RESULTS AND DISCUSSION}

\section{Physical properties of the maize}

\section{Bulk density $\left(\mathrm{kgm}^{-3}\right)$ and Particle density $\left(\mathrm{kgm}^{-3}\right)$}

There were significant differences $(\mathrm{p}<0.05)$ observed in bulk density and particle density among the different drying techniques. The bulk density of dried maize grains ranged from $665 \mathrm{kgm}^{-3}$ to $761 \mathrm{kgm}^{-3}$ (Table 2). Maize grains dried using DFD had the lowest value of $665 \mathrm{kgm}^{-3}$ while the highest value $761.4 \mathrm{kgm}^{-3}$ as that of FD. Particle density ranged from $1017.25 \mathrm{gm}^{-3}$ to $1583.06 \mathrm{kgm}^{-3}$ (Table 2). Maize grains dried using DFD had the lowest particle density of $1017.25 \mathrm{kgm}^{-3}$ while the highest value $1583.06 \mathrm{kgm}^{-3}$ was that of GHD. With the moisture range of $8.7-21.7 \% \mathrm{~d}$, the bulk density and particle density of the maize grains varied from 421.47 to $594.57 \mathrm{~kg} / \mathrm{m}^{3}$ and 954.23 to $1220.87 \mathrm{~kg} / \mathrm{m}^{3}$ [9]. In general grain densities have been found important for breakage susceptibility and hardness [10]. The average value of bulk density was found to be $790 \mathrm{kgm}^{-3}$ for maize studies [11]. The particle density of maize grain was found to vary from 1194.9 to $1267.1 \mathrm{kgm}^{-3}$ when the moisture level increased from about $10 \%$ to $18 \%$ wet basis. [12]. However, according to Waziri and Mittal [13], particle density is the significance of evaluating density for designing storage bins and silos.

\section{Porosity (\%)}

The porosity ranged from $34.87 \%$ to $53.91 \%$ (Table 1 ). Maize grains dried using DFD had the lowest content of $34.87 \%$ while the highest content $53.91 \%$ as that of GD. There was a significant difference $(p<0.05)$ which was observed for porosity among the different drying techniques. The magnitude of variation in porosity depends on bulk density as well as particle density. The average value of porosity was found to be $56.27 \%$ for maize studies. When the moisture content of grains was adjusted from $10 \%$ to $18 \%$, the porosity rose from $52.61 \%$ to $56.27 \%$ [9].

\section{Specific gravity}

There was a significant difference $(\mathrm{p}<0.05)$ which was observed in specific gravity among the different drying techniques. The specific gravity ranged from 1.01 to 1.24 , as shown in Table 1 . DFD had the lowest value (1.01) while GH had the highest specific gravity of 1.24.

\section{Shrinkage (\%)}

The shrinkage of maize at $15 \%$ moisture content ranged from $6.95 \%$ to $11.25 \%$. Sample FAD had the lowest content of $6.95 \%$ while the highest content $(11.25 \%)$ was that of GHD (Table 2). There was a significant difference $(\mathrm{p}<0.05)$ observed between all the samples. The shrinkage gives a rough idea of the weight reduction as grain is dried. The loss of volatile components such as oils and mechanical losses from cracked kernels accounts for some of the handling losses. The quantity of handling loss is determined by the initial physical state of the corn, the drying system, and the drying procedures. On-farm handling losses ranged from $0.22 \%$ to $1.71 \%$ [14]

\section{Proximate composition of the maize}

\section{Ash content (\%)}

Ash content represents the mineral content of food samples which is affected by different drying techniques to preserving the quality characteristics of maize grain. The percentage of ash content ranged from $0.8 \%$ to $1.18 \%$. Maize sample dried using DFD had a retained 
Table 2: Physical properties of each maize treatment

\begin{tabular}{|c|c|c|c|c|c|}
\hline Treatments & Bulk density $\left(\mathrm{kgm}^{-3}\right)$ & Particle density $\left(\mathrm{Kgm}^{-3}\right)$ & Porosity(\%) & Specific gravity & Shrinkage(\%) \\
\hline GHD & $756.17 \pm 0.15^{d}$ & $1583.06 \pm 0.18^{f}$ & $53.91 \pm 0.84^{\mathrm{d}}$ & $1.24 \pm 0.04^{\mathrm{e}}$ & $11.25 \pm 0.16^{\mathrm{d}}$ \\
\hline FD & $761.40 \pm 0.36^{\mathrm{e}}$ & $1494.65 \pm 0.07^{c}$ & $49.36 \pm 0.39^{b}$ & $1.17 \pm 0.22^{\mathrm{c}}$ & $10.73 \pm 0.11^{\mathrm{d}}$ \\
\hline SD & $752.47 \pm 0.30^{c}$ & $1581.97 \pm 0.11^{\mathrm{e}}$ & $52.37 \pm 0.24^{\mathrm{d}}$ & $1.24 \pm 0.25^{\mathrm{e}}$ & $9.78 \pm 0.19^{c}$ \\
\hline DFD & $665.00 \pm 0.21^{\mathrm{a}}$ & $1017.25 \pm 0.16^{\mathrm{a}}$ & $34.87 \pm 0.18^{\mathrm{a}}$ & $1.01 \pm 0.22^{\mathrm{a}}$ & $8.74 \pm 0.20^{b}$ \\
\hline FAD & $751.83 \pm 0.15^{c}$ & $1573.14 \pm 0.25^{\mathrm{d}}$ & $51.99 \pm 0.12^{\mathrm{cd}}$ & $1.24 \pm 0.30^{\mathrm{d}}$ & $6.95 \pm 0.07^{\mathrm{a}}$ \\
\hline HAD & $731.03 \pm 0.12^{\mathrm{b}}$ & $1473.37 \pm 0.31^{b}$ & $50.32 \pm 0.21^{\mathrm{bc}}$ & $1.06 \pm 0.16^{\mathrm{b}}$ & $8.32 \pm 0.13^{b}$ \\
\hline
\end{tabular}

The mean values of replicates \pm standard error. The values with the same letters are not significantly different from each other $\mathrm{p}=0.05$ on Tukey's (HSD) test.

Table 3: Proximate composition of each maize treatment

\begin{tabular}{|c|c|c|c|c|c|}
\hline Treatments & Ash (\%) & Fiber (\%) & Moisture (\%) & Fat (\%) & Protein (\%) \\
\hline GHD & $0.80 \pm 0.05^{\mathrm{a}}$ & $2.1 \pm 0.29^{a}$ & $12.13 \pm 0.39^{c}$ & $4.32 \pm 0.06^{\mathrm{a}}$ & $8.50 \pm 0.28^{a}$ \\
\hline FD & $0.99 \pm 0.06^{\mathrm{ab}}$ & $2.969 \pm 0.19^{a}$ & $9.37 \pm 0.25^{b}$ & $4.47 \pm 0.09^{a}$ & $10.09 \pm 0.31^{b}$ \\
\hline SD & $0.84 \pm 0.04^{\mathrm{a}}$ & $3.47 \pm 0.47^{\mathrm{a}}$ & $10.15 \pm 0.77^{\mathrm{bc}}$ & $4.16 \pm 0.06^{\mathrm{a}}$ & $8.75 \pm 0.38^{\mathrm{ab}}$ \\
\hline DFD & $1.18 \pm 0.01^{b}$ & $2.467 \pm 0.25^{\mathrm{a}}$ & $3.41 \pm 0.07^{\mathrm{a}}$ & $4.38 \pm 0.10^{\mathrm{a}}$ & $9.05 \pm 0.04^{\mathrm{ab}}$ \\
\hline FAD & $0.93 \pm 0.12^{\mathrm{ab}}$ & $3.07 \pm 0.40^{\mathrm{a}}$ & $9.6 \pm 0.74^{\mathrm{b}}$ & $4.57 \pm 0.14^{\mathrm{a}}$ & $9.07 \pm 0.5^{\mathrm{ab}}$ \\
\hline HAD & $1.08 \pm 0.05^{\mathrm{ab}}$ & $3.13 \pm 0.08^{\mathrm{a}}$ & $4.90 \pm 0.11^{a}$ & $4.45 \pm 0.16^{\mathrm{a}}$ & $8.72 \pm 0.12^{\mathrm{ab}}$ \\
\hline
\end{tabular}

The mean values of replicates \pm standard error. The values with the same letters are not significantly different from each other $\mathrm{p}=0.05$ on Tukey's (HSD) test.

higher value of minerals than all other maize drying methods such as GHD, FD, SD, FAD, and HAD. There is a significant difference $(\mathrm{p}<0.05)$ observed between all the samples for ash content. The ash content gives a rough idea of the total mineral amount present in the maize grain. The laboratory experiments show that maize grains contain ash content in the range of $0.81-1.35 \%$ [15]. DFD has higher ash content $1.18 \%$ compared with other treatment methods whereas GHD has shown lower ash content $(0.81 \%)$, as shown in Table 3

\section{Fiber content (\%)}

The crude fiber content of maize varies between $2.1 \%$ and $3.47 \%$ with non-significant ( $p>0.05)$ observed between all treatments. GHD had the lowest contents of $2.1 \%$ while the highest content $(3.47 \%)$ was that of SD. The remaining treatments ranged between $2.467 \%$ and $3.13 \%$, as shown in Table 3. The results of percentage crude fiber contents were found in the range of $2.1-3.47 \%$, which is slightly higher than the reported values in the literature. Qamar et al. [15] reported that the percentage of crude fiber contents was found in the range of $0.79-2.78 \%$. The crude fiber in maize largely composed of cellulose and hemicellulose provides beneficial effects in humans by a lower risk of several diseases, including cancers some heart diseases, and increasing water retention capacity during the passage of food along the gut

\section{Moisture content (\%)}

The percentage of moisture content of the dried maize samples ranged from $3.41 \%$ to $12.13 \%$ with significant differences $(\mathrm{p}<0.05)$ between all the treatments. GHD had a significantly higher value $12.13 \%$, while DFD had a significantly lower value $3.41 \%$ than all other treatments, as shown in Table 3. Maize grain with high moisture content causes several problems while storing and processing procedure. Improperly dried maize grain will result in excessive spoilage and storage losses, mold growth, and insect damage and also tends to ferment faster Moisture content is also significant to the stability and quality of grain The percentage moisture content of all the treatments studied ranged from $3.41 \%$ to $12.13 \%$; DFD has lower moisture content and GHD has higher moisture content compared to literature recorded [15], who recorded moisture content in the range of $8.98-10.45 \%$. Thus, the direct fire drying resulted in a considerable reduction in moisture content compared with the other treatments.

\section{Fat content (\%)}

Fat contents ranged from $4.16 \%$ to $4.567 \%$. SD had the lowest value $(4.16 \%)$ while FAD had the highest one $(4.57 \%)$ (Table 3$)$. There was no significantly different $(\mathrm{p}>0.05)$ observed from different drying techniques. Crude fat content in maize grain appears to have beneficial
Table 4: $\mathrm{L}^{*}, \mathrm{a}^{*}$, and $\mathrm{b}^{*}$ values of maize samples

\begin{tabular}{llll}
\hline Treatment & $\mathbf{L}^{*}$ & $\mathbf{a}^{*}$ & $\mathbf{b}^{*}$ \\
\hline GHD & $64.24 \pm 4.37^{\mathrm{a}}$ & $44.14 \pm 5.44^{\mathrm{ad}}$ & $61.83 \pm 4.31^{\mathrm{a}}$ \\
FD & $58.20 \pm 4.30^{\mathrm{b}}$ & $37.29 \pm 1.57^{\mathrm{b}}$ & $68.68 \pm 2.98^{\mathrm{b}}$ \\
SD & $60.34 \pm 3.70^{\mathrm{b}}$ & $46.91 \pm 2.98^{\mathrm{d}}$ & $60.65 \pm 1.65^{\mathrm{a}}$ \\
DFD & $68.89 \pm 5.44^{\mathrm{c}}$ & $27.62 \pm 1.96^{\mathrm{e}}$ & $74.50 \pm 3.54^{\mathrm{c}}$ \\
FAD & $64.24 \pm 3.52^{\mathrm{a}}$ & $44.14 \pm 0.98^{\mathrm{a}}$ & $61.83 \pm 1.88^{\mathrm{a}}$ \\
HAD & $58.20 \pm 2.54^{\mathrm{b}}$ & $37.29 \pm 2.91^{\mathrm{b}}$ & $68.68 \pm 2.44^{\mathrm{b}}$ \\
\hline
\end{tabular}

The mean values of replicates \pm standard error. The values with the same letters are not significantly different from each other $\mathrm{p}=0.05$ on Tukey's (HSD) test.

health effects which promote heart health. Percentage crude fat of the six treatments ranged from $4.16 \%$ to $4.57 \%$. This value is slightly similar to $4.07 \pm 0.02$ reported by Okonkwo and Agharandu [16]. DFD resulted in considerable protection in fat content compared with the other treatments, as shown in Table 3. Qamar et al. [15] reported the fat content range $3-5 \%$ in dried maize grain.

\section{Protein content (\%)}

The percentage of crude protein has shown significant differences $(\mathrm{p}<0.05)$ among different drying techniques of maize grains. GHD had the lowest value of $8.497 \%$. The crude fiber ranged from $8.5 \%$ to $10.09 \%$, as shown in Table 3. Proteins provide amino acids (for building and maintenance of the body) and energy occasionally which are important for normal body functions. The mature maize kernel consists of $10 \%$ protein content [17]. Analyzed maize varieties had protein content between $8.50 \%$ and $10.09 \%$; Okonkwo and Agharandu [16] reported a protein value of 10.79 , which falls within the range above. Qamar et al. [15] reported a protein content range 11.05-12.79\%.

\section{Color}

The color of maize at different treatments in terms of $\mathrm{L}^{*}, \mathrm{a}^{*}$, and $\mathrm{b}^{*}$ values was measured, as shown in Table 4 . Lightness (L) of maize, mean ranged from 58.201 to 68.889 , a value (redness) ranged from 27.62 to 46.913 , and b value (yellowness) ranged from 60.652 to 74.504 . Compared to different drying treatments, FD and HAD and GHD with FAD have the same color range. There were significant differences $(p<0.05)$ observed for the color of maize grains dried using different techniques.

\section{CONCLUSION}

Drying with the application of FAD is a comparably faster method with grains that had significantly better proximate composition and physiochemical properties. And also, based on this experimental study, 
the FAD technique is better when drying time and energy consumption compared to other drying techniques. Therefore, drying maize grains using the FAD technique are economical in terms of quality preservation and energy consumption.

\section{REFERENCES}

1. Coradi PC, Maldaner V, Lutz É, da Silva Daí PV, Teodoro PE. Influences of drying temperature and storage conditions for preserving the quality of maize postharvest on laboratory and field scales. Sci Rep 2020;10:1-15.

2. Dev SR, Raghavan VG. Advancements in drying techniques for food, fiber, and fuel. Dry Technol 2012;30:1147-59.

3. Jayas DS, Ghosh PK. Preserving quality during grain drying and techniques for measuring grain quality. In: $9^{\text {th }}$ International Working Conference on Stored Product Protection; 2006. p. 969-80.

4. Ape David, I, Nwanyinnaya AN, Ezekiel IU, Chinelo SI. Comparative proximate analysis of maize and sorghum bought from Ogbete main market of Enugu State, Nigeria. Greener J Agric Sci 2016;6:272-5.

5. Krokida M, Maroulis Z. Quality changes during drying of food materials. Dry Technol Agric Food Sci 2000;4:61-8.

6. Gely MC, Pagano AM. Effect of moisture content on engineering properties of sorghum grains. Agric Eng Int CIGR J 2017;19:200-9.

7. Mohsenin NN. Application of engineering techniques to evaluation of texture of solid food materials. J Texture Stud 1970;1:133-54.
8. Tavakoli H, Rajabipour A, Mohtasebi SS. Moisture-dependent some engineering properties of soybean grains. Agric Eng Int CIGR J 2009;11:1-14.

9. Sangamithra A, Gabriela JS, Prema RS, Nandini K, Kannan K, Sasikala S, et al. Moisture dependent physical properties of maize kernels. Int Food Res J 2016;23:109.

10. Heidarbeigi K, Ahmadi H, Kheiralipour K, Tabatabaeefar A. Some physical and mechanical properties of khinjuk. Pak J Nutr 2009;8:74-7.

11. Chhabra N, Kaur A. Studies on physical and engineering characteristics of maize, pearl millet and soybean. J Pharmacogn Phytochem 2017;6:1-5.

12. Bhise S, Kaur A, Manikantan M. Moisture dependent physical properties of maize (PMH-1). Acta Alimentaria 2014;43:394-401.

13. Waziri AN, Mittal JP. Design related physical properties of selected agricultural products. AMA 1997;14:59-62.

14. Shrink W. Calculating Grain Weight Shrinkage in Corn Due to Mechanical Drying. United States: Rob-Mar, Inc.; 1991.

15. Qamar S, Aslam M, Javed MA. Determination of proximate chemical composition and detection of inorganic nutrients in maize (Zea mays L.). Mater Today Proc 2016;3:715-8.

16. Okonkwo C, Agharandu U. Proximate and vitamin composition of selected cereals commonly used for weaning babies' food preparation in South-Eastern Nigeria. J Biol Agric Healthc 2017;7:71-5.

17. Prasanna BM, Vasal SK, Kassahun B, Singh NN. Quality protein maize Curr Sci 2001;81:1308-19. 